\title{
Role of RUDSETI in the Development of Women Entrepreneurship in Dakshina Kannada District of Karnataka
}

\author{
${ }^{*}$ Mrs. Shrigowri K \\ Assistant Professor in Economics, Sri Mabaveera College Moodbidri
}

\begin{abstract}
Women are the pioneers of nation. Indian culture gives great importance to women. Today, empowerment of women can be seen in all the areas of society. Entrepreneurship development of women in all the areas can be seen today. Both central and state government initiated a number of programs to foster entrepreneurial development. In 1982, an innovative initiative was taken by Sri Dharmasthala Manjunatheshwara Educational Trust, Syndicate Bank and Canara Bank finally resulted in the setting up of a very well appreciated Rural Development and Self Employment Training Institute (RUDSETI) in India to tackle unemployment issues in rural areas by providing credit acceptability and skill development programs for entrepreneurial development for the unemployed youth along with women. In this context, an attempt is made to find out the working of RUDSETI for Women Entrepreneurship in Dakshina Kannada District of Karnataka.
\end{abstract}

Keywords: RUDSETI, Self-Employment, Women Entrepreneurship Development, Hurdles of women entrepreneurship, Welfare scheme.

\section{Article Publication}

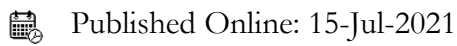

*Author's Correspondence

8 Mrs. Shrigowri K

9 Assistant Professor in Economics, Sri Mahaveera College Moodbidri

$\triangle$ shrigowrik@gmail.com

(C) 2021The Authors. Published by

International Journal of Management and Development Studies

This is an open access article under the

CC BY-NC-ND license

(https://creativecommons.org/licenses/b y-nc-nd/4.0/)

\section{Introduction}

In the words of Pandit Jawaharlal Nehru, " To awaken the people, it is the women who must be awakened. Once she is on the move, the family moves, the village moves, the nation moves". Presently women are progressing. The social and economic status of the women have takeoff to height and they are no longer restricted within the boundaries of the four walls. Earlier women were only associated with the taking care of the household and babies. But nowadays they are engaging in work fields to explore their inner talents and also to become independent and earn themselves. Now they are an efficient working woman, good homemaker, and a proud mother, daughter and sister. Women are the pioneers of nation. Indian culture gives great importance to women. Today, empowerment of women can be seen in all the areas of society. Entrepreneurship development of women in all the areas can be seen today. Both central and state government initiated a number of programs to foster entrepreneurial development.

In 1982. an innovative initiative was taken by Sri Dharmasthala Manjunatheshwara Educational Trust, Syndicate Bank and Canara Bank finally resulted in the setting up of a very well appreciated Rural Development and Self Employment Training Institute (RUDSETI) in India to tackle unemployment issues in rural areas by providing credit acceptability and skill development programs for entrepreneurial development for the unemployed youth along with women. RUDSET Institutes are continuously helping women to develop their entrepreneurial abilities through various innovative skill building training programs and Entrepreneurship Development Programs (EDPs). RUDSETI inspires women to be legendary business leaders. Training programs in the RUDSETI mouldes a legacy of women in leadership roles. RUDSETI enables to change the role of women from home maker to job maker. RUDSETI, a unique initiative in mitigating the problem of unemployment was started by Dr. D Veerendra Heggade, a visionary leader, President of SDM Educational Trust and Dharmadhikari of Dharmasthala. So far 27 RUDSETIs spread over 17 states working towards removal of poverty and 
unemployment. It has 7 branch offices in Karnataka. RUDSETI offers more than 60 types of Entrepreneurship Development Programs (EDPs) in various avenues. All the programmes ranging from one to six weeks. Empowerment of women is one of the important objectives of the RUDSETI. It provides training for the needy with free of cost.

\section{Objectives}

1. To analyze women entrepreneurial development in the Dakshina Kannada district of Karnataka.

2. To understand role of RUDSETI in encouraging women entrepreneurship.

3. To identify significance of RUDSETI in inculcating training, monitoring and development of women entrepreneurship.

4. To identify various hurdles of women entrepreneurship.

\section{Methodology}

This study is based on primary and secondary data. Primary data is collected from RUDSETI regional office and opinions are collected from the beneficiaries of RUDSETI training. Secondary data is obtained from various books and journals pertaining to the RUDSETI training throughout the nation. Updated information is also collected from the e-resource pertaining to the RUDSETI website.

\section{Women entrepreneurial development in the Dakshina Kannada district of Karnataka}

Women are an integral part of every economy. All round development of a nation would be possible only when women are considered as equal partners in progress with men. As mentioned above objective, last five decades have seen phenomenal changes in the status and work place diversity of women in Dakshina Kannada district. Empowering women entrepreneurs is essential for achieving the aims of sustainable development. The congestion hindering their growth must be eliminated to entitle full participation in the business. Women entrepreneurs can be guided by women as explorer and individualist. They have ventured to build enterprises, to find their relevance and meaning of life in themselves. In India, the year 2001 was announced as the year of Empowerment of Women by the government of India and was also marked by the compilation of the National Policy of Empowerment of Women.

As explained by Dr. A.P.J. Abdul Kalam," Empowering women is a prerequisite for creating a good nation, when women are empowered, society with stability is assured. Empowerment of women is essential as their thoughts and their value systems lead to the development of a good family, good society and ultimately a good nation ". Entrepreneurship is a multidimensional task and also the essential component in initiating and sustaining of economic development. Women entrepreneurship is one of the emerging concepts which have positive impact on women's economic empowerment. Entrepreneurship development among women is one activity that promises supporting results. By motivating, training and assisting women towards independent business enterprise, it may be possible to bring beneficial results in the development of a region. Women's entrepreneurial activities are not only a means for economic survival but also, empower them economically and enable them to contribute more to overall development. Entrepreneurship is the act of starting an industry, service or business. If entrepreneurship is to flourish, a number of conditions need to be satisfied such as finance, education and training, infrastructure, equal opportunity, support from large units and incentives.

Entrepreneurial skills involve the need for achievement, desire for taking responsibility, preference for risk, stimulation by feedback, future oriented and managerial excellence. The promotion of women's entrepreneurship is an important activity to restore economic growth, increase women's quality of life and income. Entrepreneurship has thus the potential to alleviate female poverty and, by extension, to alleviate gender inequalities. The district of Dakshina Kannada is situated on the western coast of India, consists of Mangaluru, Belthangady, Puttur, Sullia, Kadaba, Moodbidre and Bantwal taluks.In DK we can observe a large number of women entrepreneurs. But all the women are not recorded as entrepreneurs. Many are confined to home only. Out of that, we can also see self-employed women. Large number of ladies occupied different jobs as their income generating fields. 
Numerous women used their talent and skill to achieve self-sufficient. They are engaged in many jobs such as Tailoring, Music teacher, Dance teacher, Yakshagana teacher, Yoga teacher, Film actress and Artist etc. Women Entrepreneurs works in homemade industries like pickle making, pappad making etc.

\section{Role of RUDSETI in encouraging women entrepreneurship}

RUDSETI is the pioneer in Rural Entrepreneurship Development. It contributes to the women empowerment through various training programs which helps to women to become self-sufficient. Women entrepreneurship development achieved through RUDSETI trainings. Mainly Ladies Tailoring, Beauty Parlour and Computer training are some of the courses which helped women to achieve self-employment.

Dr. D. Veerendra Heggade, President of RUDSET Institutes opines that," Instead of writing someone else's account through wage employment after three to five years of collegiate education, it is more meaningful to write one's own account by embarking upon some self-employment ". RUDSET Institutes contributes more to achieve self-employment. RUDSETI continuously serving the nation with various objectives. Role of RUDSETI for the development of all the sections of the society are very significant. Some of the objectives of the RUDSETI are Promoting rural entrepreneurship, Employment generation in rural areas, creating awareness on self-employment, Confidence building in rural youth, Empowerment of women, Promotion of manufacturing and service sector. As we observed, empowerment of women is one of the main objectives of the RUDSETI. Through various training programs RUDSETI gives scope for the development of Women Entrepreneurship.

For first generation entrepreneurs various training programs are arranged. Needy candidates from women section go through several trainings like Homemade Agarbathi making, Dairy farming and Vermi compost making, Beauty Parlour Management, Vastra Chitra Kala Udyami (Embroidery and fabric painting), Papad, Pickle and Masala Powder Entrepreneur, Women's Tailoring, Candle Making. After getting these training programmes, another type of training programis arranged for established entrepreneurs. Skill updating training programs like, advanced beauty parlour, advanced dress designing for women, photography, video editing, etc.

Table 1: Development training programmes under RUDSETI:

\begin{tabular}{|c|l|c|c|c|c|c|c|}
\hline \multirow{2}{*}{ S1 no } & \multirow{2}{*}{ Programmes } & \multicolumn{2}{|c|}{$2018-19$} & \multicolumn{2}{c|}{$2019-20$} & \multicolumn{2}{c|}{$\begin{array}{c}\text { Cumulative } \\
\text { (from the beginning) }\end{array}$} \\
\cline { 3 - 8 } & $\begin{array}{c}\text { No. of } \\
\text { prgms } \\
\text { held }\end{array}$ & $\begin{array}{c}\text { No. } \\
\text { candidates } \\
\text { trained }\end{array}$ & $\begin{array}{c}\text { No. of } \\
\text { prgms } \\
\text { held }\end{array}$ & $\begin{array}{c}\text { No. of } \\
\text { candidates } \\
\text { trained }\end{array}$ & $\begin{array}{c}\text { No. of } \\
\text { prgms held } \\
\text { candidates } \\
\text { trained }\end{array}$ \\
\hline 1 & Rural Development & 1 & 15 & 1 & 26 & 157 & 6287 \\
\hline 2 & $\begin{array}{l}\text { Entrepreneurship } \\
\text { Orientation }\end{array}$ & 3 & 175 & 1 & 100 & 238 & 11743 \\
\hline 3 & $\begin{array}{l}\text { Human Resource } \\
\text { Development }\end{array}$ & 2 & 80 & 11 & 428 & 64 & 2438 \\
\hline
\end{tabular}

Source: Activity Report, 2019-20, RUDSET institute Ujire.

The above table shows that, out of various development programmes highest priority is given to Entrepreneurship Orientation. The cumulative number of programs and trainees under entrepreneurship orientation is 238 and 11743 respectively. As compared to other programmes, this number is highest one.

Table 2: Women Oriented Training programmes:

\begin{tabular}{|r|l|l|r|l|}
\hline \multicolumn{3}{|c|}{ 2018-19 } \\
\hline S1 No & Training Programs & Programs sponsored & Training period & $\begin{array}{l}\text { Number of Candidates } \\
\text { Trained }\end{array}$ \\
\hline 1 & Women Tailor & NRLM* & 60 days (2sets) & 59 \\
\hline 2 & Computer Accounting & NRLM & 30 days & 30 \\
\hline 3 & Beauty Parlour Management & NRLM & 30 days & 34 \\
\hline
\end{tabular}

Source: Activity Report, 2019-20, RUDSET institute Ujire.

*NRLM- National Rural Livelihoods Mission 
Out of the above 3 programs, tailoring and beauty parlour management are only for women candidates. Table 2 reveals that 59, 30 and 34 candidates are trained under tailoring, computer accounting and beauty parlour management respectively.

\section{Welfare schemes}

One of the primary objectives of the RUDSET institute is the welfare of weaker section. The institute conducting women specific programs every year. During the course of training, special emphasis is given to the welfare scheme of state and central govt. and other various departments.

Table 3: Share of weaker sections in RUDSETI

\begin{tabular}{|c|c|c|c|c|c|c|c|c|c|}
\hline \multirow[t]{2}{*}{ S1 no } & \multirow[t]{2}{*}{ Category } & \multicolumn{2}{|c|}{ 2018-19 } & \multicolumn{2}{|c|}{ 2019-20 } & \multicolumn{2}{|c|}{$2020-21$} & \multicolumn{2}{|c|}{$\begin{array}{l}\text { Cumulative } \\
\text { ( from the } \\
\text { beginning) }\end{array}$} \\
\hline & & No & $\%$ Share & No & $\%$ Share & No & $\%$ Share & No & $\%$ Share \\
\hline 1 & SC & 72 & 9.52 & 62 & 8.17 & 35 & 9.16 & 2346 & 9.54 \\
\hline 2 & ST & 59 & 7.8 & 65 & 8.57 & 34 & 8.9 & 1631 & 6.63 \\
\hline 3 & $\mathrm{OBC}$ & 505 & 66.8 & 505 & 66.64 & 254 & 66.5 & 13894 & 56.51 \\
\hline 4 & Minority & 79 & 10.45 & 89 & 11.74 & 37 & 9.69 & 2479 & 10.08 \\
\hline 5 & Others & 41 & 5.43 & 37 & 4.88 & 22 & 5.75 & 4240 & 17.24 \\
\hline \multirow[t]{2}{*}{6} & Total & 756 & 100 & 758 & 100 & 382 & 100 & 24590 & 100 \\
\hline & Of which & & & & & & & & \\
\hline 1 & Women & 310 & 41 & 255 & 33.64 & 171 & 44.76 & 6959 & 28.3 \\
\hline 2 & Physical handicapped & 4 & 0.53 & 1 & 0.13 & 2 & 0.52 & 133 & 0.54 \\
\hline
\end{tabular}

Source: Activity Report, 2019-20, 2020-21 RUDSET institute Ujire.

Table 3 revels that the share of weaker section details, cumulative number of persons 24590 of which 6959 are women. Share of women candidates is $28.3 \%$.

\section{Significance of RUDSETI inculcating training, monitoring and development of women} entrepreneurship.

RUDSET Institutes are seen as an important tool for empowering women. Some training programmes are women oriented. RUDSETI empowered women's status in family and in community, giving them more power to participate in decision making process and self-employment. Each unit of RUDSETI has a Local Advisory Committee (LAC) with representatives of sponsor organizations, Government Officials and eminent personalities. It periodically reviews and assists the progress of RUDSETI. An Officer on deputation, with experience in development banking sponsor banks manages each RUDSETI units. After giving training it will do the post training follow-up. The innovation of RUDSETI training is the post training follow-up to encourage the motivation level and overcome difficulties of new entrepreneurs. It co-ordinates with other agencies influencing the setting up of self-employment enterprises. Banks have supported in a big way by financing the trainees to establish their ventures. Business counselling and project consultancy services are provided on an ongoing basis, besides networking for business development. RUDSETI includes information course module for general EDPs. Usually, it focuses to create awareness about support systems and process of setting an enterprise and also it increases the confidence level among the trainees of RUDSETI. It increases information seeking competency also.

\section{Various hurdles of women entrepreneurship}

It is a challenging task for women to take up self-employment and become entrepreneurs. The problems faced by women of developing countries are of different extent than those of women of developed countries. The 
common problem faced by women are inequality of power sharing with men and in particular in the decision making at all levels, lack of awareness of their rights, insufficient machinery at all levels to promote advancement of women. These constraints emerge from dominant position of males, economic dependence, traditional values, poverty and discrimination. At the same time a number of problems such as social, attitudinal and institutional barriers, inadequate employment opportunities, family ties, lack of education, travel restrictions, lack of leadership qualities, fear of failure, the absence of an apex organization to oversee and promote their activities, inappropriate and inadequate training, insufficient information and so on have hindered women from using opportunities of development. This in a way the negative impact of their risk-taking ability. To empower women, women entrepreneurship development acts as a major tool in the low developed and developing countries. Both government and non-government agencies are investigating with many programs to promote women entrepreneurship.

\section{Conclusion}

The training programs conducted by RUDSETI have empowered women economically, socially, and psychologically. Economic independence impacted more on their involvement in many activities and had exposed them to the environment, which have great magnitude of changing their abilities to understand their selves as well as their relations to the society. This had also resulted in developing positive attitude forwards themselves and to the society. Thus entrepreneurship among women helps them to empower economically but also contributes towards elevation of poverty and economic development of the nation. It is observed that among the trainees that when they come out of the RUDSETI, their confidence level and the motivation is so high that they will be ready to face any challenges in their new ventures.

\section{References}

Activity Report, 2019-20, 2020-21 RUDSET institute Ujire.

Al-Shodhana- A Multi Disciplenery refreed research vol VI No2 July 2018.

Dr. Norbert Lobo; Indian Economy Issues and Reforms, Mangala Publications, Mangalore.

http://rudsetitraining.org/ : Annual report RUDSET 2019-20

http://slbckarnataka.com/ : state level bankers committee.

Human Development Report 1995

Women entrepreneur in India - Approach to education and empowerment by V Basil hans and Sowjanya S Shetty.
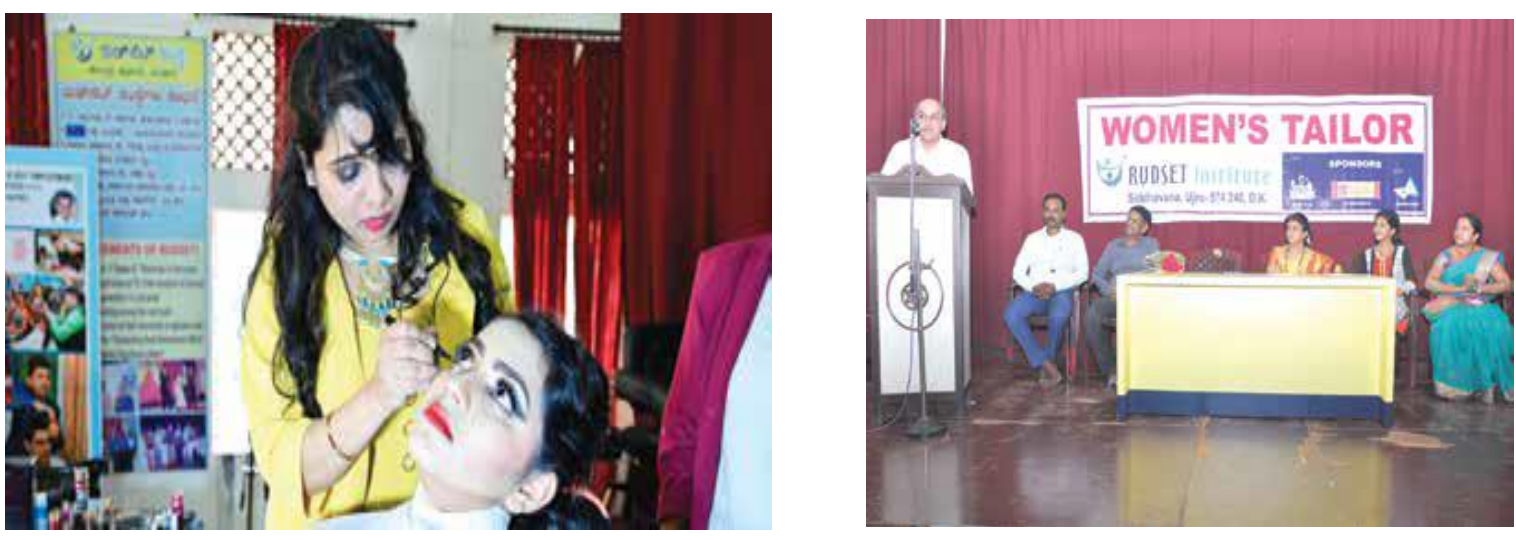

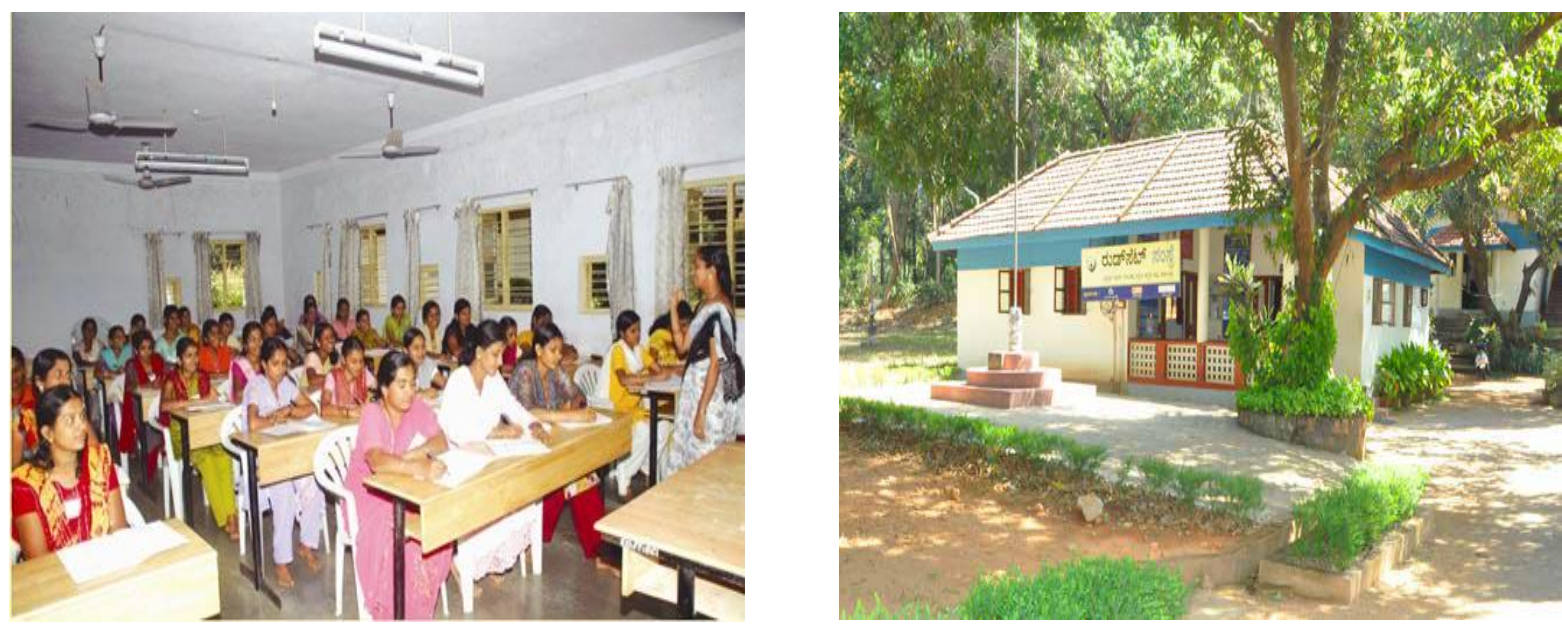

Source: RUDSET Institute Ujire. 